\title{
APLIKASI E MONITORING PELAYANAN SEKOLAH PADA DINAS PENDIDIKAN
}

\author{
${ }^{1}$ Marhasan \\ ${ }^{2}$ Silvia Ratna \\ Fakultas Teknologi Informasi, Universitas Islam Kalimantan \\ Muhammad Arsyad Al Banjari Banjarmasin \\ Email : marhasan.bjm@gmail.com \\ Fakultas Teknologi Informasi, Universitas Islam Kalimantan \\ Muhammad Arsyad Al Banjari Banjarmasin \\ Email : via.Borneo@gmail.com
}

\begin{abstract}
Abstrak
Telah dilakukan penelitian tentang aplikasi e-monitoring dan pemanfaatan standar pelayanan minimal sekolah pada Dinas Pendidikan Kabupaten Tanah Laut dengan menggunakan . Penelitian ini bertujuan mengetahui : (1) Membangun aplikasi emonitoring dan pemanfaatan standar pelayanan minimal sekolah yang dapat memberikan data dan informasi tentang ketercapaian pencapaian standar pelayanan minimal. (2) Membangun aplikasi e-monitoring dan pemanfaatan standar pelayanan minimal sekolah yang bisa menampilkan kondisi Ketercapaian standar pelayanan minimal sekolah per indikator ketercapaian. (3) Membangun aplikasi e-monitoring dan pemanfaatan standar pelayanan minimal sekolah yang menghasilkan penyajian informasi untuk sekala prioritas pembangunan sekolah. (4) Menerapkan membangun aplikasi e-monitoring dan pemanfaatan standar pelayanan minimal sekolah pada lingkungan Dinas Pendidikan Kabupaten Tanah Laut. Penelitian menggunakan rancangan program Hypertext Preprocessor (PHP).
\end{abstract}

Kata kunci : Aplikasi e - monitoring, PHP

\section{PENDAHULUAN}

Kabupaten Tanah Laut terdapat 235 Sekolah Dasar (SD) dan 56 Sekolah Menengah Pertama (SMP) yang terbagi di 11 Kecamatan. Pada saat penyusunan anggaran belanja daerah dan bantuan dari Pemerintah Provinsi maupun pusat kita harus memiliki data terlebih dahulu mengenai kondisi bangunan sekolah yang akan mendapat bantuan, adapun kendala yang ada di beberapa sekolah yang berjarak ratusan kilometer dari pusat Kota Pelaihari, sehingga memerlukan tenaga dan waktu yang cukup lama bagi Dinas Pendidikan untuk memonitor kemajuan pencapaian Standar Pelayanan Minimal (SPM) pada jenjang pendidikan dasar yang akan memberi pengaruh terhadap kebijakan dalam menentukan jumlah anggaran yang diperlukan untuk mencapai target pemenuhan Standar Pelayanan Minimal tersebut. Kondisi tersebut akhirnya menghambat proses pembuatan laporan terkait pengangaran pembangunan, karena tidak akuratnya data sekolah dijenjang pendidikan dasar yang mana sudah memenuhi Standar Pelayanan Minimal (SPM) atau tidak dikarenakan pembuatan rekapitulasi masih dilakukan secara manual.

Kondisi tersebut akhirnya menghambat proses pembuatan laporan terkait pengangaran pembangunan, karena tidak akuratnya data sekolah dijenjang pendidikan dasar yang mana sudah memenuhi Standar Pelayanan Minimal (SPM) atau tidak dikarenakan pembuatan rekapitulasi masih dilakukan secara manual. Berdasarkan latar belakang tersebut maka perlu adanya penelitian tentang penggunaan aplikasi e-monitoring pelayanan sekolah pada dinas pendidikan. 
Tujuan dari penelitian ini adalah mencari analisis data ketercapaian Standar Pelayanan Minimal (SPM) Sekolah, mengetahui secara detail dan akurat jumlah sekolah yang sudah memenuhi standar pelayanan minimal pada pendidikan dasar, membuat sebuah sistem yang dapat memberikan penyelesain atas permasalah yang menyakut Standar Pelayanan Minimal (SPM) pendidikan dasar.

Adapun Manfaat yang diharapkan dari penelitian ini yaitu Lebih Memudahkan Dinas Pendidikan Kabupaten Tanah Laut untuk mengetahui persentase ketercapaian Standar Pelayanan Minimal (SPM) Pendidikan Dasar, Penelitian ini akan mempercepat dan mempermudah pelaporan tentang Standar Pelayanan Minimal (SPM) Pendidikan Dasar untuk instansi yang memerlukan dan memudahkan kebijakan - kebijakan Pemerintah Daerah dalam menentukan anggaran belanja untuk bidang pendidikan.

\section{METODE PENELITIAN}

Metodologi penelitian yang digunakan dalam mengerjakan laporan penelitian ini adalah metode deskriptif, yaitu metode penelitian yang menggambarkan secara sistematika dan akurat mengenai keadaan-keadaan nyata yang berjalan pada saat penelitian. Gambaran tersebut diperoleh dengan cara mengumpulkan, mengklasifikasikan, menyajikan, serta menganalisis. Metode pengumpulan dan pemilihan sampel yang akan digunakan sebagai berikut.

- Metode Pemilihan Sampel

Metode pemelihan sampel yang dipakai dalam penelitian ini adalah random sampling atau teknik acak. Nama teknik ini sangat populer dan banyak dianjurkan penggunaannya dalam proses penelitian. Pada teknik acak ini, secara teoretis, semua anggota dalam populasi mempunyai probabilitas atau kesempatan yang sama untuk dipilih menjadi sampel untuk mendapat responden yang hendak dijadikan sampel.

- Metode Pengumpulan Data

Teknik pengumpulan data yang akan digunakan untuk mengumpulkan data adalah sebagai berikut:

Analisis dan Perancangan Sistem
Analisa Sistem

Analisis sistem (systems analysis) dapat didefinisikan sebagai penguraian dari suatu sistem informasi yang utuh ke dalam bagianbagian komponennya dengan maksud untuk mengidentifikasikan dan mengevaluasi permasalahan- permasalahan, kesempatankesempatan, hambatan-hambatan yang terjadi dan kebutuhan-kebutuhan yang diharapkan sehingga dapat diusulkan perbaikanperbaikannya

\section{Analisis Sistem Yang berjalan}

Sistem pendataan standar pelayanan minimal sekolah (SPM) masih secara manual yaitu dengan metode konvensional dimana operator sekolah mengisi formulir dan direkap menggunakan mikrosoft exel dan memerlukan waktu yang sangat lama, dan rata-rata jarak sekolah dengan Dinas Pendidikan jauh ditambah jumlah sekolah yang banyak. Sehingga memerlukan waktu yang lama untuk memperoleh data yang diinginkan. Kekurangan inilah yang menjadi kendala ketika pimpinan pada rapat kerja diminta untuk menyampaikan bagaimana kondisi ketercapaian standar pelayanan minimal sekolah. Sistem pendataan yang konvensional ini harus dikembangkan sehingga menjadi sistem yang modern yang memberikan kemudahan kepada Dinas Pendidikan Kabupaten Tanah Laut.

Aplikasi e-monitoring ini dibuat untuk memberikan suatu penyampaian informasi dan data tentang ketercapaian standar pelayanan minimal sekolah (SPM) secara online dalam rangka untuk memudahkan pimpinan dalam kebijakan penetapan Anggaran Pendapatan dan Belanja Daerah (APBD). Teknologi ini diharapkan dapat memberikan memanfaatkan dengan baik dan menjadi sarana pendukung bagi Dinas Pendidikan Kabupaten Tanah Laut untuk meningkatkan kualitas pendidian di Kabupaten Tanah Laut.

\section{Analisis Kebutuhan Sistem}

Analisis kebutuhan Sistem merupakan analisis yang dibutuhkan untuk menentukan spesifikasi kebutuhan sistem. Spesifikasi ini juga meliputi elemen atau komponenkomponen apa saja yang dibutuhkan untuk sistem yang akan dibangun sampai dengan sistem tersebut diimplementasikan. Analisis 
kebutuhan ini juga menentukan spesifikasi masukan yang diperlukan sistem, keluaran yang akan dihasilkan sistem dan proses yang dibutuhkan untuk mengolah masukan sehingga menghasilkan suatu keluaran yang diinginkan. Kebutuhan non- fungsional yang diusulkan adalah adanya komputer yang terkoneksi dengan jaringan internet agar transaksi dapat berjalan secara maksimal serta memudahkan dalam hal pengolahan database.

Sistem Yang Di Kembangkan

Dari analisis yang telah dilakukan maka perlu adanya pengembangan sebuah sistem yang dapat membantu dalam mengelola data informasi standar pelayanan minimal sekolah. Pengisian mandiri berbasis aplikasi ini merupakan bantuan informasi teknologi yang diharapkan dapat menunjang serta mempermudah dalam hal pengidentifikasian kebutuhan yang berkaitan dengan data ketercapaian standar pelayanan minimal sekolah. Pengumpulan data informasi ketercapaian standar pelayanan minimal sekolah dapat lebih efisien dan efektif baik dari segi waktu dan biaya, dan dari hasil identifikasi itu sendiri menjadi rujukan penentuan arah kebijakan pembangunan pendidikan yang akan dilaksanakan.

\section{Rancangan Model Sistem}

Diagram Konteks

Diagram konteks adalah diagram yang terdiri dari suatu proses dan menggambarkan ruang lingkup suatu sistem. Diagram konteks merupakan level tertinggi dari DFD yang menggambarkan seluruh input ke sistem atau output dari sistem.

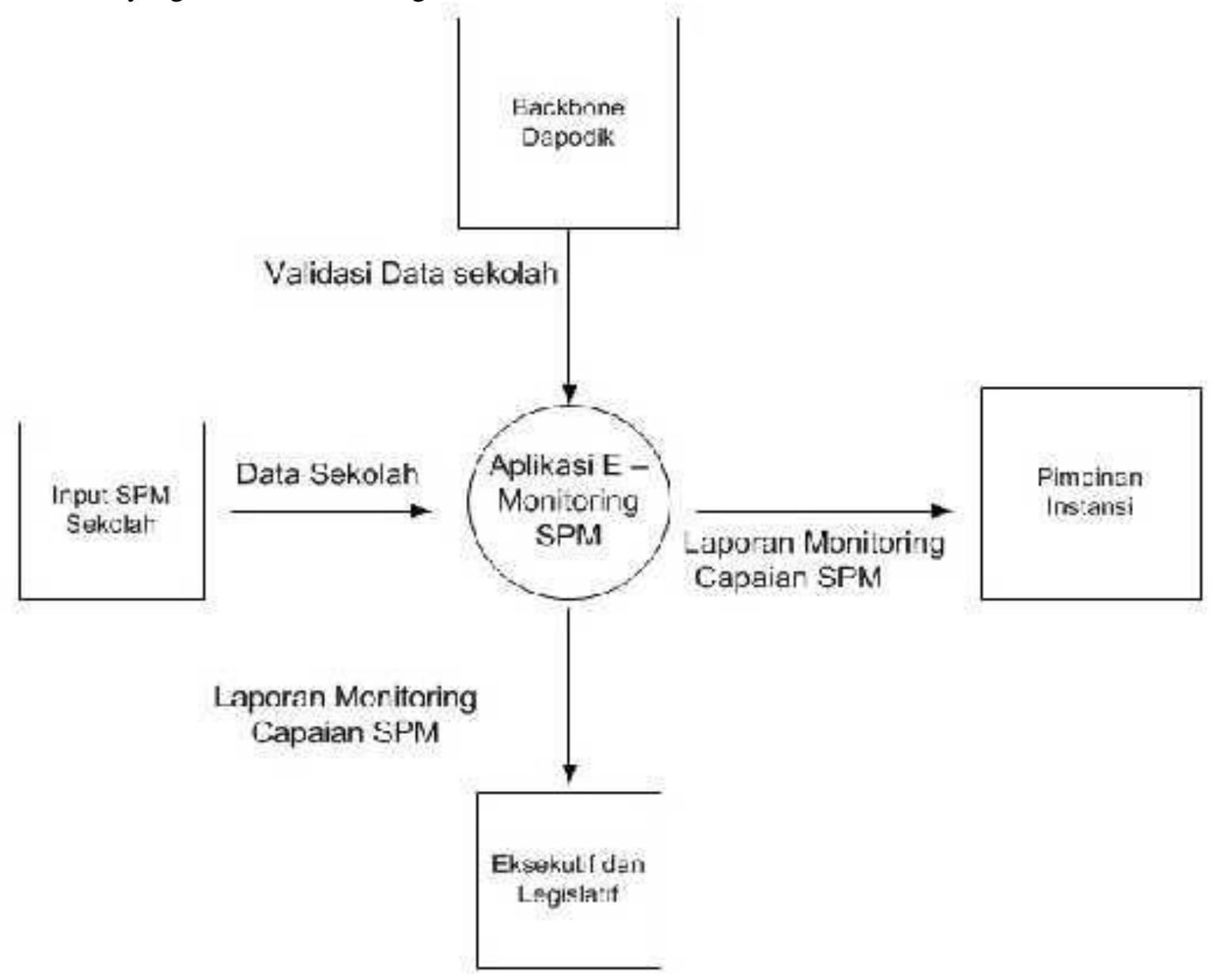

Gambar 1. Diagram Konteks 


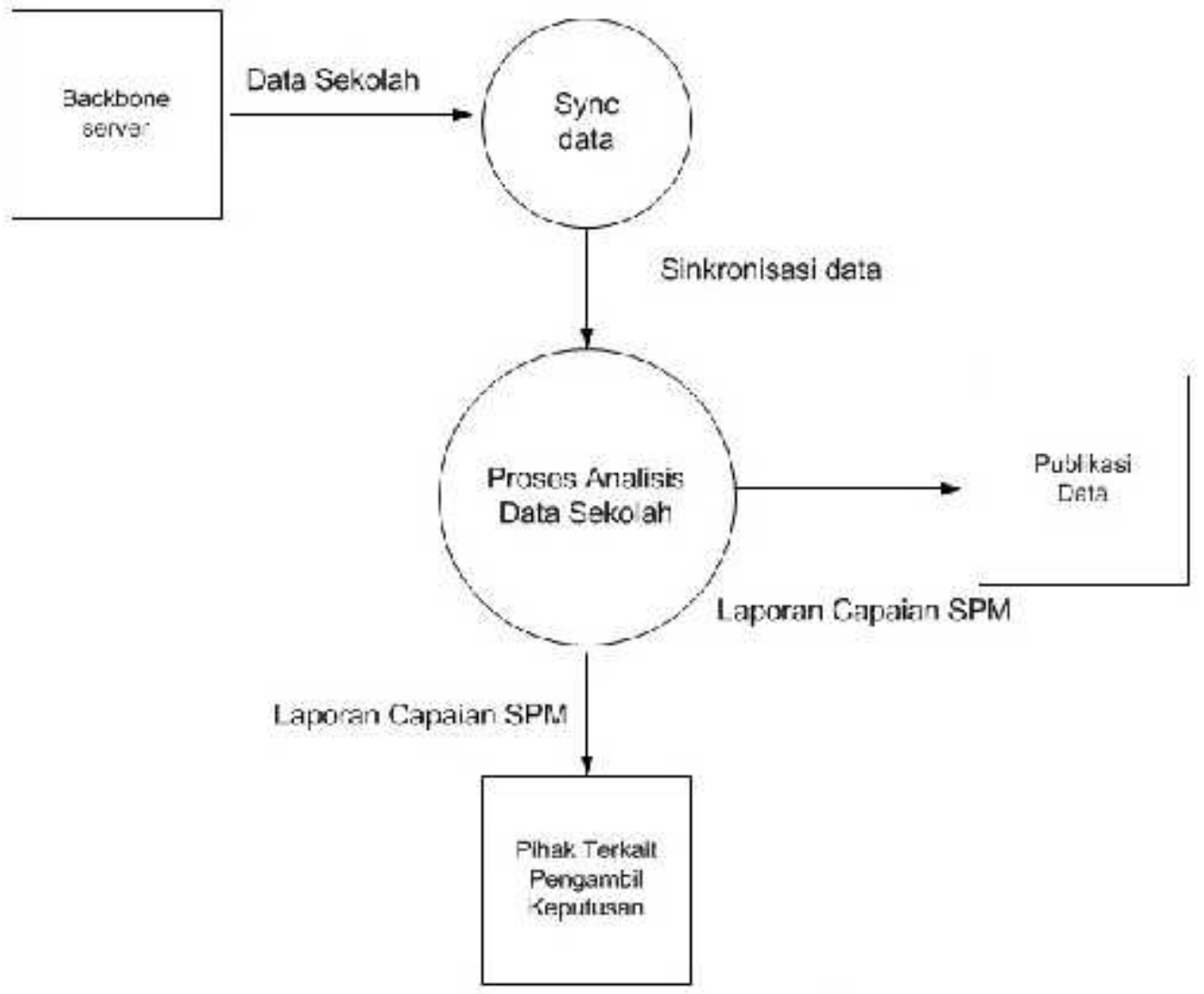

Gambar 2 Data Flow Diagram (DFD) Level 0

B:done jener

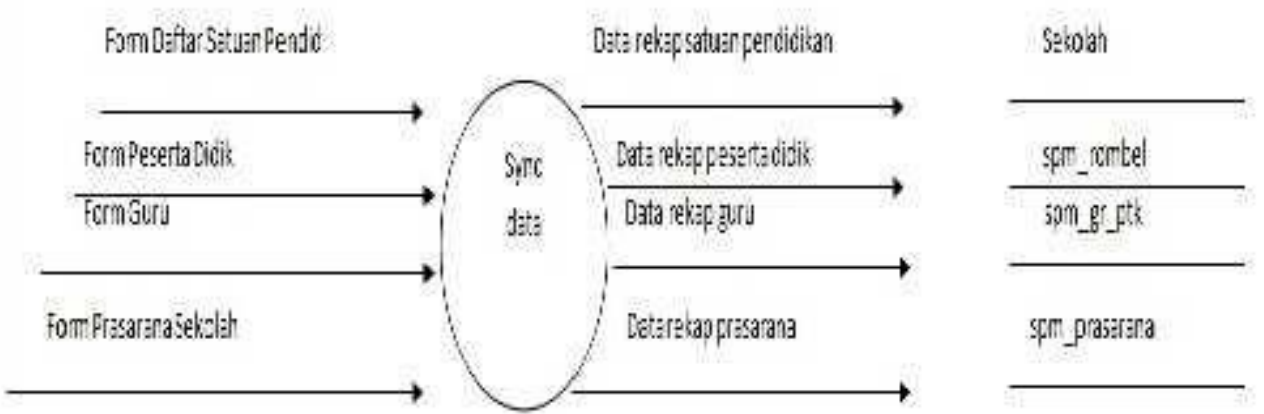

Gambar 3 DFD Level 1 Proses 1 


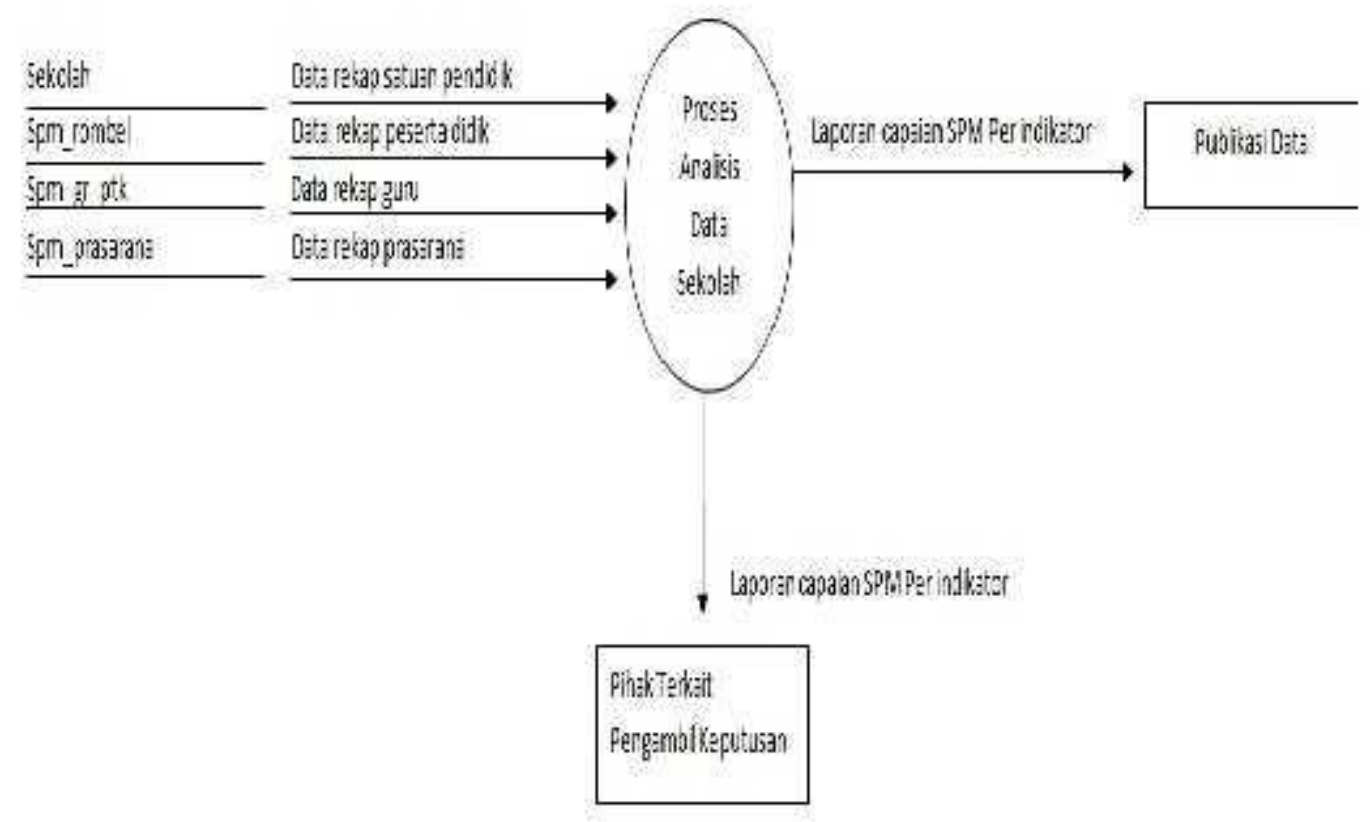

Gambar 4 DFD Level 1 Proses Analisis Data Sekolah

\section{HASIL DAN PEMBAHASAN}

Tampilan antar Muka Pengguna

Form Log in

\section{Sistem Informasi Pelaporan Standar Layanan Minimal (SPM)}

Dinas Pendidikan Dan Kebudayaan

Kabupaten Tanah Laut

Username

Password

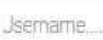

oassword.

Gambar 5 Tampilan Form Log in

Form ini akan tampil awal ketika halaman utama dijalankan, tampil sebagai sidebar yang mana akan berubah isinya ketika dilakukan login. Langkah selanjutnya mengisi username dan password yang benar maka pengguna bias masuk ke halaman utama.
Halaman beranda adalah tampilan setelah login berhasil dan menampilkan jumlah keseluruhan jumlah satuan pendidikan jenjang SD dan SMP serta ketercapain SPM dengan grafik yaitu sarana dan prasarana, pendidik dan tenaga 
pendidik, dan kurikulum perjenjang pendidikan serta jumlah sekolah perjenjang pendidikan.

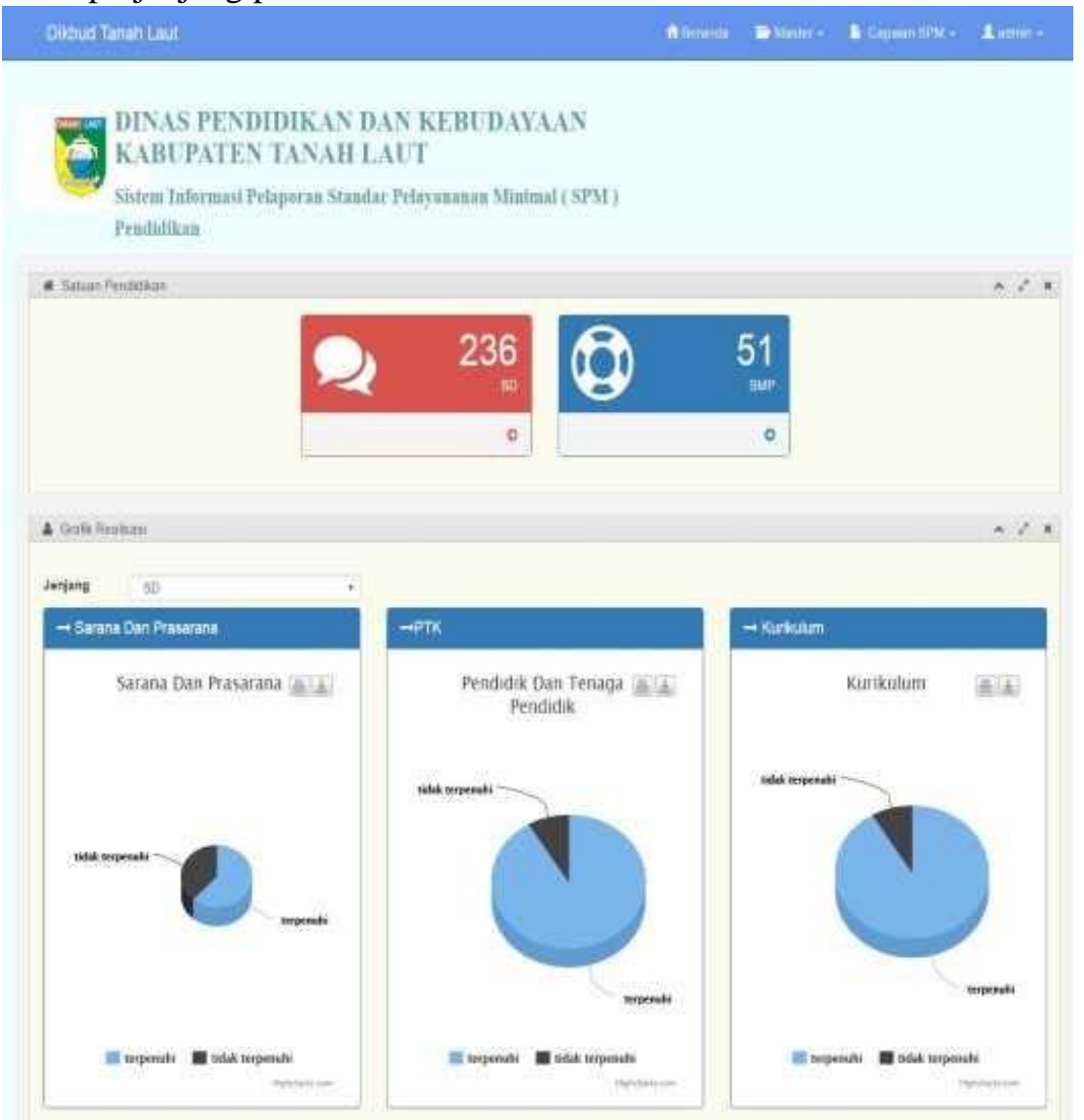

Gambar 6 Tampilan Beranda 


\begin{tabular}{|c|c|c|c|c|}
\hline \multicolumn{5}{|c|}{ 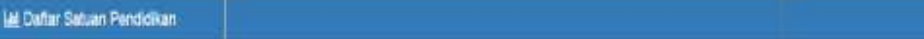 } \\
\hline \multirow{2}{*}{\multicolumn{5}{|c|}{ 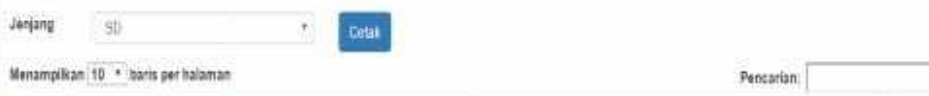 }} \\
\hline & & & & \\
\hline No & REM & Nams & Aanst & Srave \\
\hline 1 & 35souts & 50 KETERIBATAW 1 & 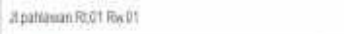 & MESEA| \\
\hline 2 & xissory & SD NEGERI BATANW 2 & A Heoikadr Rill Fie? & IEBEAI \\
\hline 3 & moouss & SO NEOERI BATACAN? & Fiauctífeta & NeGra! \\
\hline 4 & monorar & 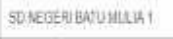 & Dusun Lnauft:1a.t & REGEAI \\
\hline 5 & swasoss & SO NEGERI BATUMLAH? & Dusur Santane & REGEAT \\
\hline I & 2xosos & SD NEGER BNDTUNOXII & $x$ sath hingen ints & NEGEA \\
\hline 7 & 200035? & SO KEGEVU BATUTUKOKU 2 & Abernas Pet2010 & NEBEAI \\
\hline 1 & 203045 & 5D HEGERIBACUTUNGSU? & Exupr tanumg Vea & REGH \\
\hline$b$ & sowosts & SD NEGEGUELA RSH' & Desa Euntan & KEUEN \\
\hline 10 & m20030s & SD NEOERI BUSA ASH2 2 & Dusur strikilya Rit. 12 Rov of & NEGEAI \\
\hline
\end{tabular}

Gambar 7 Form Daftar Satuan Pendidikan Jenjang SD

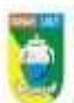
DINAS PENDIDIKAN DAN KEBUDAYAAN KABUPATEN TANAHLAUT

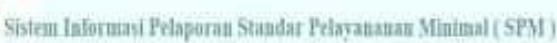
Peuililikan

\section{Lostar Situn Pondolem}

Seriani sup c crat

Memampitan $10 \cdot$ boris per tulaman

\begin{tabular}{|c|c|c|c|c|}
\hline \multicolumn{3}{|c|}{ Menampilan 10 " boris pet talaman } & \multicolumn{2}{|c|}{ Fencerian: } \\
\hline Nos & vpsi & Nano: & Nianat & Staus \\
\hline 1 & 30306639 & SLP NEGES I PWWTFATAN & Jisal: Whyz: & NELER: \\
\hline 2 & 30304918 & SUP NECERS 2 PANTFATAL & Hetedikats & NECES \\
\hline 3 & 3020 ts: & SUP NESEFY 1 PAMMFATAN & 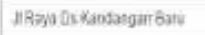 & NEGER: \\
\hline 4 & $3030863 ?$ & SIP NECERE 1 TakisiNO & 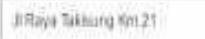 & MEIESal \\
\hline 5 & Jo3060e9 & SMP WECES? TAKCUNG & Hilsya Thanie & NEGeri \\
\hline 6 & 36306653 & 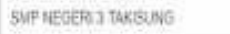 & Desa 5 moer kama & Neseri \\
\hline 7 & 10304953 & 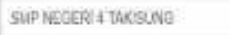 & Desa Kuala Tambangan & NEGe: \\
\hline i & $305+1638$ & 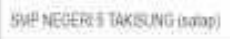 & H Sevp Rा। & NETEeri \\
\hline 1) & 30300640 & SUP TEGEe I RiRaU & Desa Pidana Luas Re i No 18 & NEGER \\
\hline 10 & 30347233 & MP NEGER A KAALU & Dest ltalua 2ave & NESESI \\
\hline
\end{tabular}

5tome 1 to 1 o ot 5 sames

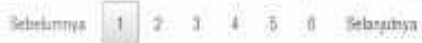

\section{Gambar 8 Form Daftar Satuan Pendidikan Jenjang SMP}

Jurnal Ilmiah Fakultas Teknik "Technologia" 
DINAS PENDIDIKAY DAN KEBUDAYAAI

KABUPATEN TANAH LAIT

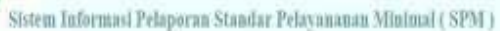
Pentiditian

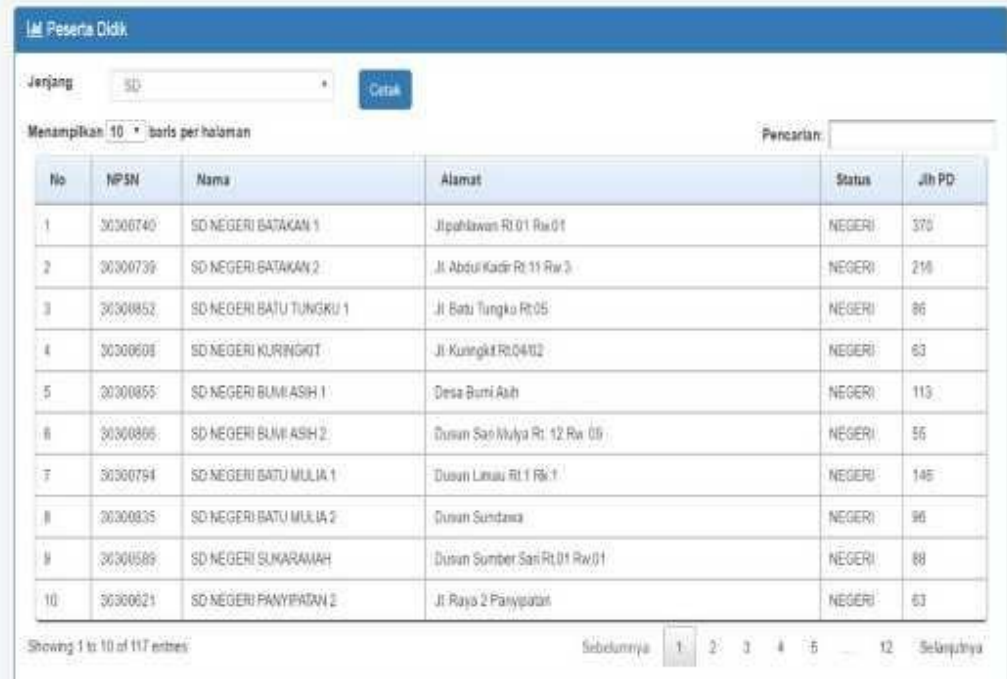

Gambar 9 Form Daftar Peserta Didik Jenjang SD

DINAS PENDIDIKAN DAN KEBUIDAYAAN

KABUPATEN TANAH LAUT

Sistem Informas Pelapora Standar Pelaviaiaiain Minimal ( SPM)

Peadililian

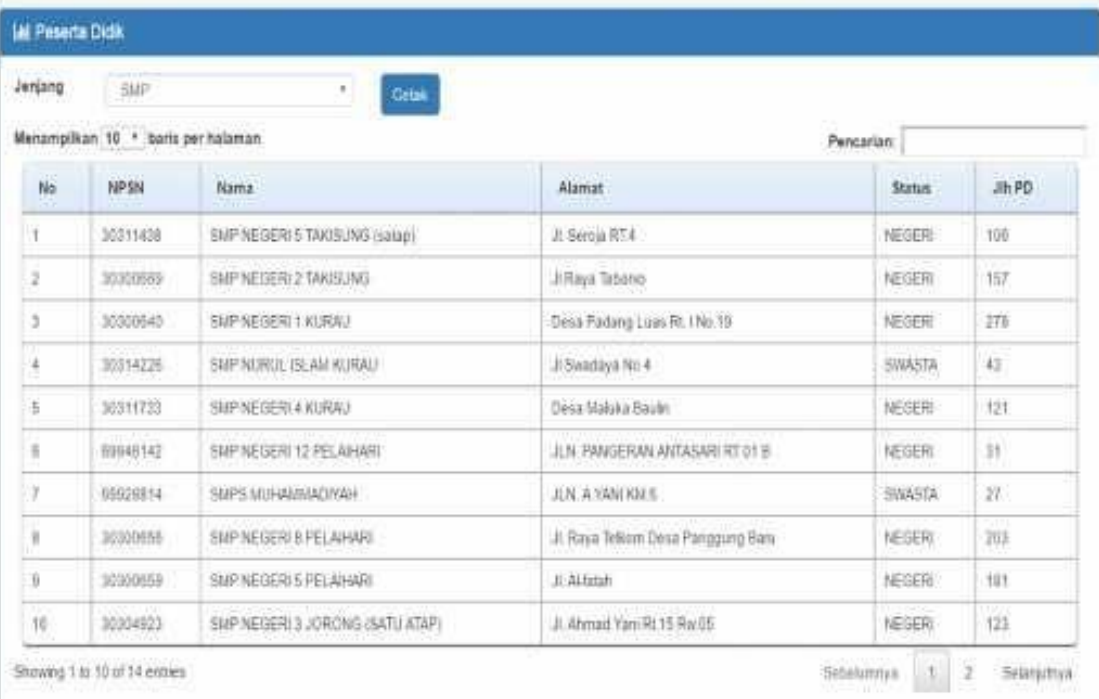

Gambar 10 Form Daftar Peserta Didik Jenjang SMP 


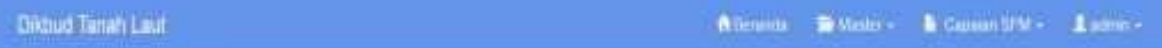

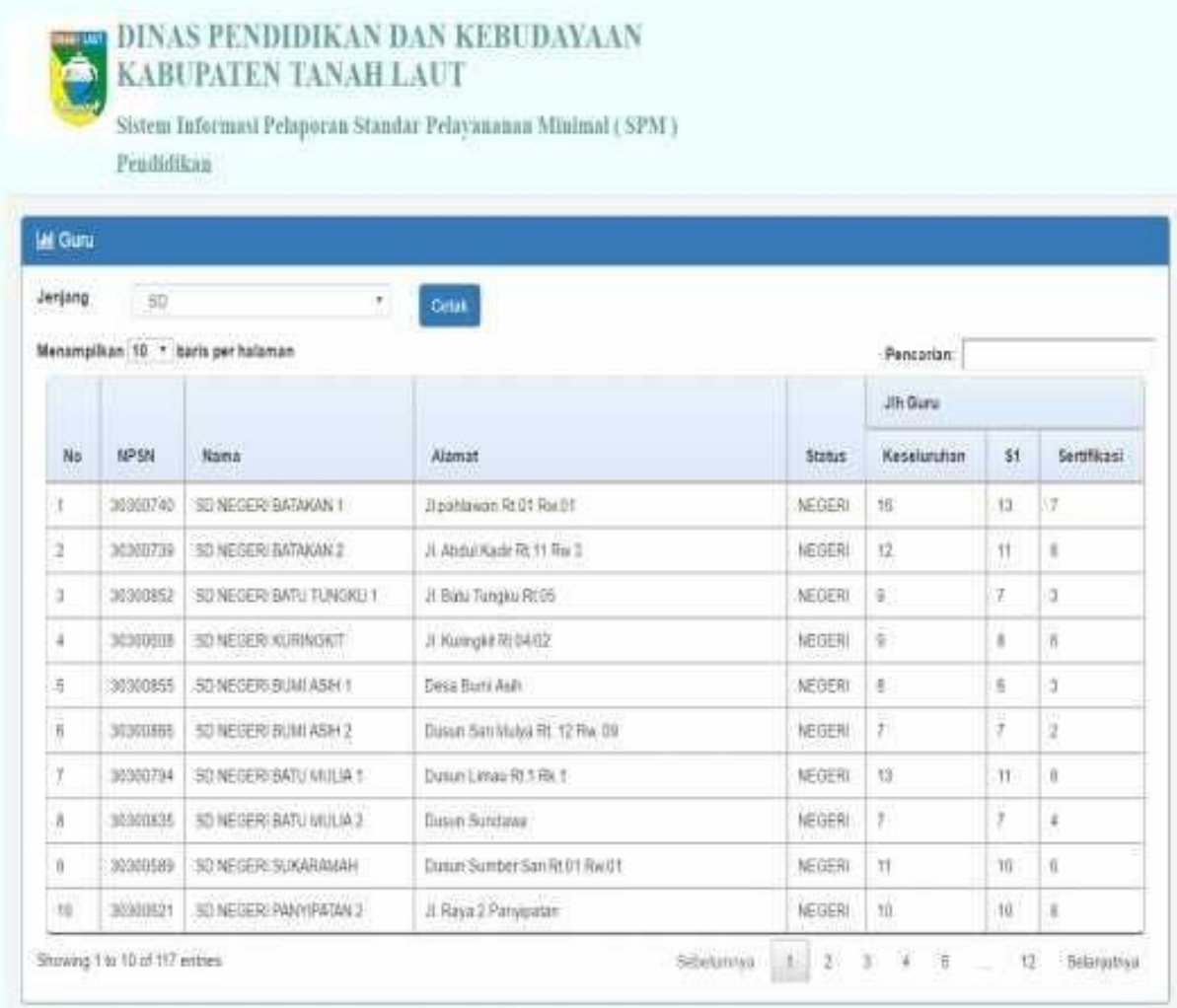

Gambar 11 Form Daftar Guru Jenjang SD

\section{Kesimpulan}

Berdasarkan hasil penelitian dan pembahasan yang telah dibuat dan dikemukakan, maka dapat ditarik kesimpulan yaitu :

Aplikasi e-monitoring pada Dinas Pendidikan Kabupaten Tanah Laut lebih terorganisir dengan baik dari sebelumnya yang belum ada sama sekali.

Aplikasi e-monitoring yang dibuat sangat membantu Dinas pendidikan Kabupaten Tanah Laut dalam menentukan ketercapaian standar pelayanan minimal sekolah per indikator perjenjang pendidikan persatuan pendidikan Aplikasi tersebut dibuat, dengan harapan standar pelayanan yang sekolah berikan dapat di pantau terus proses perkembanganya dan permasalahan- permasalahan apa saja yang sedang dihadapi sehingga bisa dengan cepat dalam penangananya, dan juga dapat maksimal dan mudah dalam pengambilan keputusan tentang kebijakan penganggaran untuk pembangunan sekolah kedepannya.

\section{Saran}

Berdasarkan hasil penelitian serta kesimpulan yang telah dikemukakan berikut ini ada beberapa saran yang diharapkan menjadi masukan untuk pengembangan aplikasi ini :

Kekurangan aplikasi ini adalah masih ada indikator Standar Pelayanan Minimal (SPM) yang belum tersedia pada aplikasi ini.

Untuk Pengembangan aplikasi ini kedepannya bisa ditambahkan dengan melengkapi indikator Capaian SPM yang belum tersedian yaitu penilaian pendidik dan penjamin mutu, indikator ketersediaan buku. 
5.DAFTAR PUSTAKA

Arbie. (2004). Manajemen Database dengan MySQL. Yogyakarta: Andi. Abidin, Z. (2010). Konsep Dasar Sistem Informasi.

Budiharto, Widodo, (2002). Aplikasi Database Dengan SQL Server 2000 Dan

Visual Basic 6, Jakarta : PT. Elek Media Komputindo.

Hartono, Jogiyanto. (1999). Analisis Dan Disain Sistem Informasi: pendekatan terstruktur teori dan praktek aplikasi bisnis.

Hasibuan, Z. A. (2007). Metodologi Penelitian Pada Bidang Ilmu Komputer dan

Teknologi Informasi. Jakarta.

Husni Iskandar Pohan \& Kusnassriyanto Saiful Bahri, (1997). Pengantar

Perancangan Sistem, Jakarta : Erlangga.

R, Stephens and Ronald, Plew (2000). Database Design, 1st ed. Sams Publishing.
Sutarman. (2003). Membangun

Aplikasi Web dengan PHP dan

MySQL.Yogyakarta: Graha Ilmu.

Uma Sekaran, (2006). Metodologi Penelitian untuk Bisnis, Edisi 4, Buku 1, Jakarta: Salemba Empat.

Wibisono, D. (2013). Panduan Menyusun Skripsi, Tesis, dan Disertasi.

Yogyakarta: CV. ANDI OFFSET. 